\title{
Analysis of Using Gasoline-Corncob Waste Bioethanol Blends in Four-Stroke Motorcycle Engine onto Exhaust Emission and Compression Ratio
}

\author{
Hanapi Hasan ${ }^{1}$, Hasan Maksum², Safri Gunawan ${ }^{3}$, E Eswanto ${ }^{4}$, Sapitri Januariyansah ${ }^{5}$ \\ \{hanapi_hasan@unimed.ac.id ${ }^{1}$, hasan_maksum@yahoo.co.id ${ }^{2}$, safri_gunawan@unimed.ac.id ${ }^{3}$, \\ eswanto@unimed.ac.id $\overline{\mathrm{d}}^{4}$, sapitrijanuariyansyah@unimed.ac.id $\left.{ }^{5}\right\}$ \\ Department of Mechanical Engineering, Universitas Negeri Medan, Indonesia ${ }^{1,3,4,5}$, \\ Department of Automotive, Universitas Negeri Padang, Indonesia ${ }^{2}$
}

\begin{abstract}
This research utilizes corncob waste for making bioethanol by RON 109. The objective of this research is to get the best performace of exhaust emission by mixing gasoline RON 90 from E5, E10, E15, E20, to E25, and 10:1, 11:1 and 12:1 of compression ratio. In addition, the control variable covered $1400 \mathrm{rpm}, 2400 \mathrm{rpm}$, and $3400 \mathrm{rpm}$ engine speed. The testing data of exhaust emission was taken only on the carbon monoxide (CO) and hydrocarbon (HC). The result on this biethanol from corncob waste showed that the lowest exhaust emission on carbon monoxide and hydrocarbon and recom mended to be used was found on E10 fuels at 10:1 compression ratio, and E20 fuels at 11:1 compression ratio. The result obtained from this research demonstrated that the carbon monoxide and hydrocarbon emissions that produced by corncob waste bioethanol were environmently friendly compared to gasoline use only (E0).
\end{abstract}

Keywords: Bioethanol, Corncob Waste, Gasoline, Compression Ratio, Exhaust Emission.

\section{Introduction}

Fossil fuels, particularly petroleum is a major energy source for vehicles where its availability is becoming more insufficient and could not be renewed [1,3]. The issue on energy crisis and enviromental pollution due to the emission product of fossil fuels combustion is the most significant problem in the world nowadays. Referred to the data gathered from Central Bureau of Statistics (2019), within the last seven years, the number of vehicles increases twice with $7 \%$ in average for the annual increase [2].

On one hand, the increasing number of vehicles gives a positive impact on the economic development. In contrast, it allows bad impact as well by the increase of harmful gases derived from the fossil fuels ignition on the vehicles. Harmful gases and millions of exhaust is obviously the main contributor in air pollution among many countries including Indonesia [3]. This pollution imposes negative effect on the environment and tremendous consequences for human health like respiratory disorders, cancer, heart attack, and other malignancies. In addition, this exhaust emission also can cause mental retardation on children. Besides the air pollution, the second issue that should be faced by people is the inadequate energy needed in running their vehicles $[4,8]$.

The energy crisis and the damage on the environment establish motivation to learn and evaluate the alcohol as the fuel on gasoline engine [1]. Ethanol has several advantages compare to gasoline, such as the subtraction on CO, volatile organic compounds (VOC), unburned hydrocarbon emission (UHC), and adequate anti-knock characteristic (denotation), that make the possibility of using the engine compression ratio getting higher. As the ethanol is a liquid fuel, its storage and emission is likewise the gasoline [6]. The use of bioethanol becoming the 
vehicles fuels is a safe alternative, and can reduce the dependency on petroleum. As a matter of fact, ethanol is also used for cosmetic and pharmacy purposes [9]. Alcohol fuel, especially ethanol can be produced from the renewable sources such as sugarcane, cassava, corn, and whey which is the cheese production waste with $22,26 \%$ shared production [6], pineapple skin and sugarcane residues that produce $95 \%$ ethanol [10], and other types of biomass waste. One of the potential materials to be extracted for ethanol raw material is corncob.

In Indonesia, corn is one of food commodities with increasing productivity level. Based on the data from Central Bureau of Statistics, in 2018 the corn production in Indonesia is as much as 29.612.435 ton. Regardless, the utilization of corn all this time is only on the corn kernels. Other part of the corn as the cob has not yet been optimally used. The use of the corncob as the raw material for producing bioethanol is closely related with the chemical components contained in it, which is coarse fibres and cellulose, where they can be extracted into bioethanol. Moreover, the corncob is composed of $46 \%$ cellulose, $36 \%$ hemicelluloses, and $16 \%$ lignin. Fairly high content of cellulose in the corncob makes it possible to be used as the raw material in producing bioethanol. However, this bioethanol extracted from the corncob has not been adequately used as the gas fuel, even it is disposed as wastes. This entire time, it is often seen that stacks of corns are being wasted and burned. If this situation is kept occuring, it will add unbeneficial amount of waste. Hence, in the absence of any adequate action, it will harm the environment [11].

The aim of this research is to investigate how much the influence of using the ethanol from the corncob waste in four-stroke motorcycle engine onto carbon monoxide and hydrocarbon emissions.

\section{Bioethanol}

Among community, ethanol is widely known as alcohol. It derives from Arabic word alkuhl (al kohl), which means volatile compounds. It is a clear, colorless, acceptable unique aroma, liquids at room temperature, and flammable [2,3]. The alcohol species which is commonly used is $\mathrm{CH} 3 \mathrm{OH}$, and called as methyl alcohol (methanol), $\mathrm{C} 2 \mathrm{H} 5 \mathrm{OH}$ called as ethyl alcohol (ethanol), and $\mathrm{C} 2 \mathrm{H} 7 \mathrm{OH}$ called as isopropyl alcohol (IPA) or 2-propanol. In industrial world, alcohol refers to ethanol or ethyl alcohol or methyl alcohol with chemical formula $\mathrm{C} 2 \mathrm{H} 5 \mathrm{OH}$.

Ethanol in its pure form or as gasohol (the blend of gasoline and ethanol (alcohol)) is used as an alternative fuel for vehicles. The use of ethanol is due to its boiling point likewise heptane (evaporates at similar engine temperature), distilled within the gasoline, and results to less pollutant $[1,4]$.

\section{Gasoline (Pertalite RON 90)}

Gasoline is Hydrocarbon compound that is produced from petroleum. For gasoline engine takes gasoline, and for diesel engine takes diesel oil (petroleum-distillate fuel). Pertalite is a gasoline with renewed quality [5]. It is a type of fuels intended for two-wheeled, three-wheeled, and four-wheeled vehicles [7]. Furthermore, pertalite is a term taken in defining the complex mixture of several refined hydrocarbons of crude oil used as the engine fuel [5]. It is derived from the naphtha distillation process where its composition can be utilized as the fuel for internal combustion engine. Naphtha itself is known as light oil where its properties are between gasoline and kerosene.

\section{Maize}

In 2018 , the national maize production reached 29.612 .435 ton, and was estimated to escalate to 35 millions ton by 2019 . This corn contains of $30 \%$ of waste deriving from its cob. If it is converted with the total amount of production in 2018 , Indonesia has the potentiality contributing 9.883.730 ton corn waste. It can be said it is a huge amount of waste and is going to be potentential if it is appropriately utilized. How ever, the corncob is one of lignocellulosic 
wastes that is widely available in Indonesia. It is a plantation waste containing cellulose, hemicellulose, and lignin.

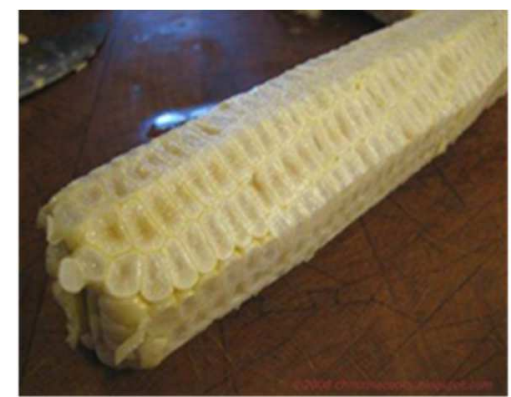

Fig. 1. Corncob

The chemistry and physiscs characteristics of this corncob is compatible with constitute of alternative energy (bioethanol), whereby the lignin complex compounds level in the corncob is $6,7-13,9 \%$, consisted of 39,8\% hemicellulose and 32,3-45,6\% cellulose. Cellulose is barely found in an absolute condition, as it is always bonded with other components which are lignin and hemicellulose [4].

\section{Research Method}

This research design is categorized into experimental approach. This approach is a research that utilized in investigating the influence of certain treatment onto other treatments within controlled condition. It applied the experiment model of post-test only control design where the use of this model was based on the assumption that the experiment and the comparison group chosen through voting was absolutely equivalent.

Variable is the object or the focus of a research. As for this research, its variable was four-stroke motorcycle engine. Here, the data to be retrieved was the content level of Carbon Monoxide and Hydrocarbon, and also increasing the compression ratio on the usage of pertalite and bioethanol.

Table 1. Some properties of gasoline and ethanol

\begin{tabular}{lll}
\hline & Gasoline & Ethanol \\
\hline Chemical formula & C8H18 & C2H5OH \\
RON & 90 & 109 \\
Density $\left(\mathrm{kg} / \mathrm{m}^{3}\right)$ & 733 & 794 \\
Molecular weight $(\mathrm{g} / \mathrm{mol})$ & 101,5 & 46,07 \\
Oxygen (mass\%) & 0 & 34,7 \\
Lower heating value $(\mathrm{MJ} / \mathrm{kg})$ & 42,5 & 26,95 \\
Latent heat $(\mathrm{kJ} / \mathrm{kg})$ & 287 & 854 \\
Stoichiometric air/fuel ratio & 14,7 & 9 \\
\hline
\end{tabular}

The data collection was performed by initial testing to obtain the reference data using octane 90 gasoline (Pertalite) with standard compression ratio. Further, for the testing data, was conducted by using the blends of bioethanol octane 109 with E5, E10, E15, E20 and E25. This testing was utilized fourgass analyzer at the engine speed of 1400, 2400 and $3400 \mathrm{rpm}$. As an addition, in the testing data, compression ratio increment was performed which had been changed into 10:1,11:1, and 12:1. On each engine speed changes, the data was recorded covering the emission of carbon monoxide and hydrocarbon. Meanwhile, the data collection tools were in the form of tables, further was going to be analyzed which resulted into percentage graphs. 
Table 2. Test Engine Specifications

\begin{tabular}{cll}
\hline No & Item & Specification \\
\hline 1 & Engine type & Four-stroke SOHC, Air-cooled \\
2 & Number of cylinder & 1 \\
3 & Capacity & $109,1 \mathrm{cc}$ \\
4 & Bore & $50 \mathrm{~mm}$ \\
5 & Stroke & $55,6 \mathrm{~mm}$ \\
6 & Compression ratio & $9,0: 1$ \\
7 & Maximum torque & $8,4 \mathrm{Nm} / 5500 \mathrm{rpm}$ \\
8 & Maximum Power & $6,2 \mathrm{~kW} / 7500 \mathrm{rpm}$ \\
\hline
\end{tabular}

\section{Results and Discussion}

In accordance with the desired research aim that finding out how much the influence of using ethanol from the corncob wastes in four-stroke engine onto carbon monoxide and hydrocarbon. Moreover, the research of carbon monoxide and hydrocarbon emissions was performed for three speeds at $1400 \mathrm{rpm}, 2400 \mathrm{rpm}$, and $3400 \mathrm{rpm}$, and then another three times testing on each rpm. Below was the description of the influence on using bioethanol from the corncob wastes as the gasoline blend.

\subsection{The Influence of Carbon Monoxide (CO) Emission}

\section{a. Compression Ratio 10:1}

The CO level in exhaust is totally influenced by the comparison of the oxygen in the amotsphere and fuel amount. $\mathrm{CO}$ emission on the exhaust is also one of combustion completeness indications in the combustion chamber. Fig-2 shows the changes on $\mathrm{CO}$ exhaust emissions onto the engine speed changes. In a standard condition, gasoline produces $\mathrm{CO}$ emission with an average volume of $1,648 \%$. The biggest $\mathrm{CO}$ emission decrease resulted by gasoline-bioethanol blended fuel at 10:1 compression ratio was obtained in E10 blends, with $58,1 \%$ average reduction.

On average, bioethanol experienced the significant decrease at the 2400 speed, and an increase at 3400 speed. This data analysis result was in accordance with the properties of ethanol fuel where the ethanol Research Octane Number (RON) was higher than gasoline. It was also seen from the potentiality of resisting high pressure and temperature before igniting the combustion. This was due to the reason that SI engine efficiency was depended upon the compression ratio and fuels with high octane that was totally appropriate for high compression ratio [1]. 


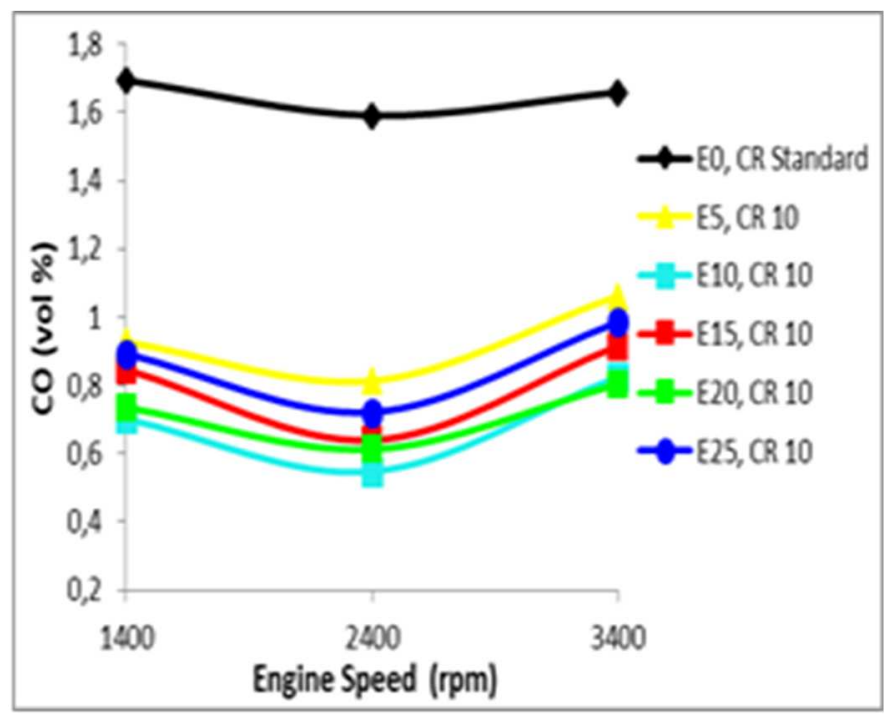

Fig. 2. Variation of $\mathrm{CO}$ emission versus engine speed

\section{b. Compression Ratio 11:1}

By the increase of compression ratio up to $11: 1, \mathrm{CO}$ emissions was decreasing into 58,7 $\%$ in E20 blends comparing to gasoline. Iodice et al [1] stated that the $34,7 \mathrm{wt} \%$, oxygen content in ethanol was able to elevate the combustion efficiency and cause the bioethanol combustion temperature becoming higher, as the oxygen concentration was much provided in the engine cyclinder. It resulted into a more complete combustion process (bonded effect), and the decrease of the occurence on $\mathrm{CO}$ and $\mathrm{HC}$ emissions level.

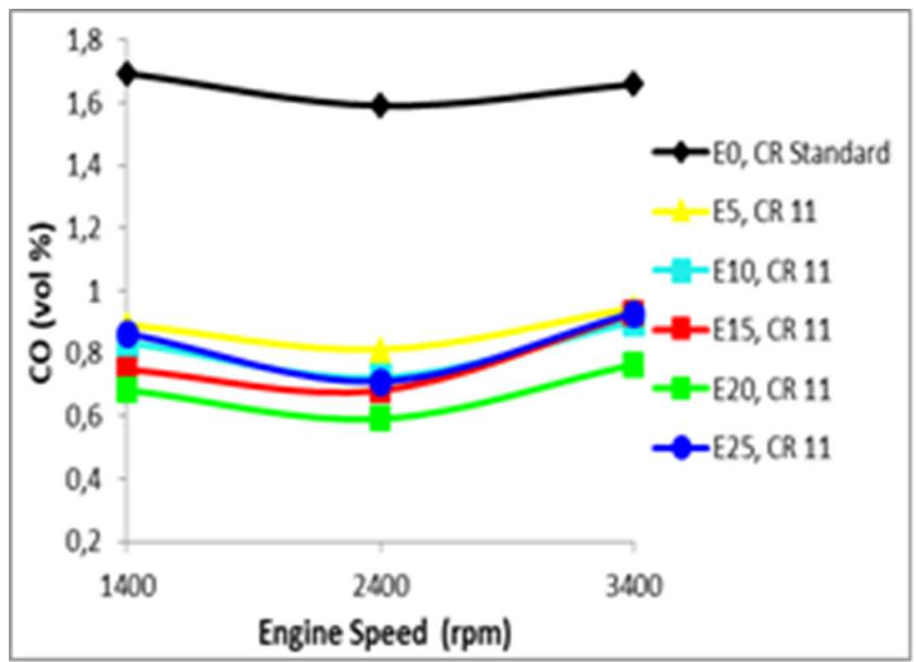

Fig. 3. Variation of $\mathrm{CO}$ emission versus engine speed 


\section{c. Compression Ratio 12:1}

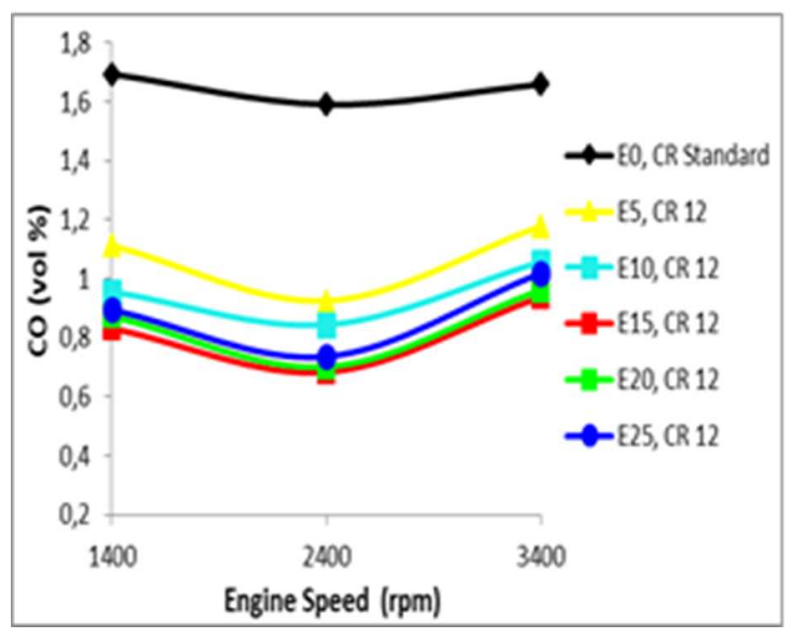

Fig. 4. Variation of $\mathrm{CO}$ emission versus engine speed

The graphic above indicated the average of the maximum $\mathrm{CO}$ emissions decrease produced by bioethanol at 12:1 compression ratio was found in E15 blends, the reduction was 50,4 \% compared with E0 fuels. Hence, CO 15 emission value was still high compare to the value of $\mathrm{CO}$ in the blends, and other compression ratios. It was occured because of high compression ratio was inappropriate to be used into low bioethanol blends.

\subsection{The Influence of Hydrocarbon (HC) Emission}

\section{a. Compression Ratio 10:1}

Hydrocarbon emission was decreasing as the engine speed increased. The standard testing utilized the gasoline (pertalite), and obtained the speed of $260 \mathrm{ppm}$ for $\mathrm{HC}$ emissions value. Whereas by using bioethanol at 10:1 compression ratio, the average of the lowest $\mathrm{HC}$ emission decrease was in E10 blends at the speed of 203 ppm, decreasing for 21,9\% compared with E0 fuels. This result was in line with the one stated by hasan et al [3], pointed out that the oxygen content in ethanol chemistry formula led the blend of fuels and oxygen becoming homogeneous, so it decreased the $\mathrm{HC}$ and $\mathrm{CO}$ emissions level.

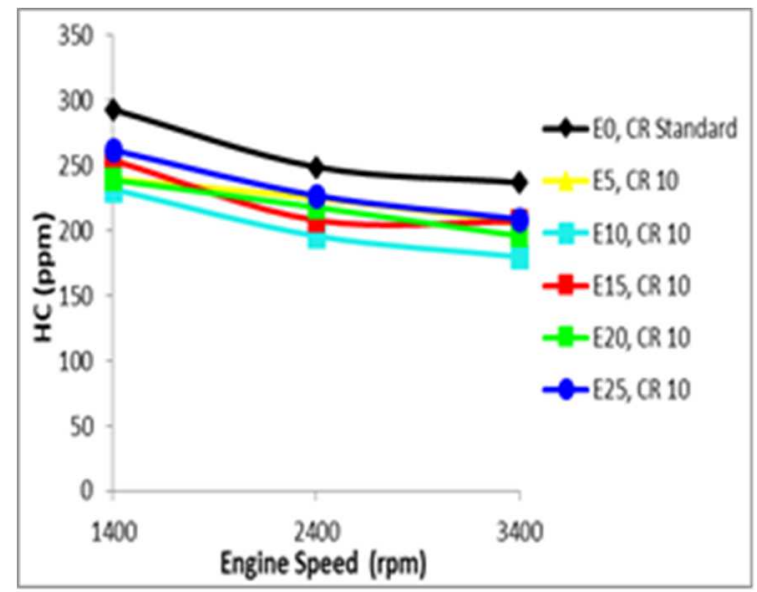

Fig. 5. Variation of $\mathrm{HC}$ emission versus engine speed 


\section{b. Compression Ratio 11:1}

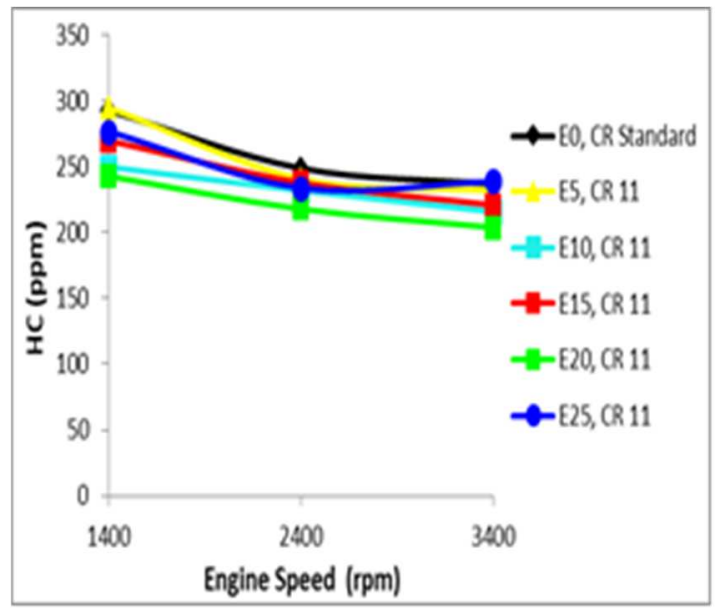

Fig. 6. Variation of $\mathrm{HC}$ emission versus engine speed

Moreover, Fig- 6 shows the correlation between the $\mathrm{HC}$ content changes in the exhaust onto the engine speed increment. During the standard condition, gasoline resulted $\mathrm{HC}$ emission in the average speed of $260 \mathrm{ppm}$. The average of the maximun $\mathrm{HC}$ emission decrease produced by bioethanol fuel at 11:1 compression ratio was in E20 blends, the average reduction was 14,6 $\%$ compared with E0 fuels.

\section{c. Compression Ratio 12:1}

From the graphic below, it can be seen that the HC emission decrease was not significant. The average of the minimum $\mathrm{HC}$ emission decrease at 12:1 compression ratio was in $\mathrm{E} 15$ blends at the speed of $227 \mathrm{ppm}$, the reduction was $12,7 \%$ compared with E0 fuels. The decrease of $\mathrm{HC}$ emission in E25 blends was not different considerably with E15, the reduction was of 11,1\% compared with E0 fuels.

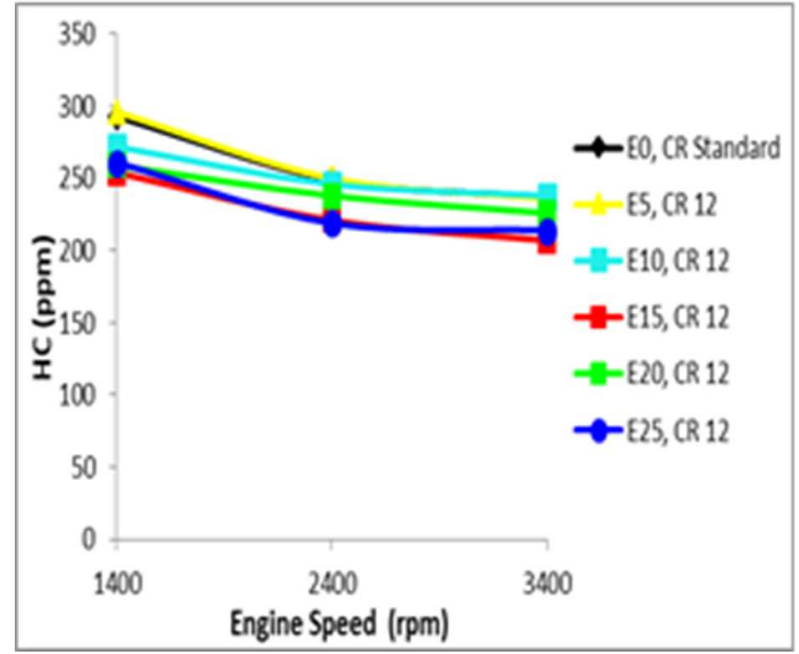

Fig. 7. Variation of $\mathrm{HC}$ emission versus engine speed 


\section{Conclusion}

The influence of using corncob waste bioethanol on carbon monoxide and hydrocarbon in four-stroke motorcycle engine by performing pertalite testing yields $1,648 \%$ vol CO and 260 ppm HC. The testing by using the blends of bioethanol E5, E10, E15, E20, and E25 obtains the result of the lowest $\mathrm{CO}$ and $\mathrm{HC}$ emissions decrease, at 10:1 compression ratio, which are $0,691 \%$ vol CO and the $203 \mathrm{ppm}$ for HC. Additionally, at 11:1 compression ratio, the lowest CO is 0,680 $\%$ vol and $222 \mathrm{ppm}$ for HC. Furthermore, for $12: 1$ compression ratio, the lowest CO is $0,817 \%$ vol and $227 \mathrm{ppm}$ for $\mathrm{HC}$.

The testing result shows that the carbon monoxide and hydrocarbon emissions resulted from corncob waste bioethanol is more eco-friendly than gasoline (pertalite). The lowest testing result of carbon monoxide and hydrocarbon emissions and recommended that can be used is in E10 bioethanol at 10:1 compression ratio, and E20 fuels at 11:1 compression ratio. The results of E10 and E20 bioethanol demonstrates that the emission content of carbon monoxide and hydrocarbon is still under the restriction of State Minister for the Environment Regulatory No 05, year 2006 concerning the Treshold of Vehicles Exhaust Emission, which are 5,5 \% vol for $\mathrm{CO}$ concentration and the speed of $2400 \mathrm{ppm}$ for $\mathrm{HC}$ on idle cycle in four-stroke motorcycle engine.

\section{References}

[1] Iodice, P., Senatore, A., Langella, G. and Amoresano, A.: Effect of Ethanol-Gasoline Blends on CO and HC Emissions in Last Generation SI Engines within The Cold-Start Transient: An Experimental Investigation. Applied Energy. Vol. 179. Pp. 182-190. (2016)

[2] Costa, R.C. and Sodré, J.R.: Compression Ratio Effects on An Ethanol/Gasoline Fuelled Engine Performance. Applied Thermal Engineering. Vol. 31. Pp. 278-283. (2011)

[3] Hasan, H., Sudarmanta, B., and Paloboran, M.: Influence of the Compression Ratio and Duration Injection on Performance and Emission of Sinjai Engine Type Flexible Fuel Engine $150 \mathrm{cc}$ Fueled Bioethanol E70. IPTEK, Journal of Engineering. Vol 3. No. 3. (2017)

[4] Halderman, James D.: Automotive Fuel And Emission Control System. New Jersey. Pearson Education Inc. (2012)

[5] Heywood, J.B.: Internal Combustion Engines Fundamentals, McGraw-Hill, Inc. United States. (1988)

[6] Rufino. CH, Lima. AJTBD, Mattos. AP, Allah. FUM, and Bernal. JLL.: Exergetic analysis of a spark ignition engine fuelled with ethanol. Energy Conversion and Management. Vol. 192. Pp. 20-29. (2019)

[7] Turns, S.R.: An Introduction To Combustion Concepts and Applications. 2nd edition, McGraw-Hill. United States. (2000)

[8] Riris. ID, Gultom. ES, Lazuardi. G, Silalahi. A, and Purba. D.: Antibacterial Activity of Extract Ethyl Acetate and Ethanol of Raru (Vatica pauciflora Blume). AISTSSE EAI. (2018)

[9] Winarso. R, Hidayat. T, Wibowo. R, Qomaruddin, Kabib. M.: Design Of Continuous Reflux System Bioethanol Distillator With Production Capacity Of 5 Liter/Hour. ICCSET EAI. (2018)

[10] Simorangkir. M, Nainggolan. B, and Silaba. S.: Secondry metabolities phytochemical analysis of n-Hexane, Ethyl Acetate and Ethanol Extracts of sarang banua (clerodendrum fragrans vent willd) leaves. AISTSSE EAI. (2018) 
[11] Qian. Y, Liu. G, Guo. J, Zhang. Y, Zhu. L, and Lu. X.: Engine performance and octane on demand studies of a dual fuel spark ignition engine with ethanol/gasoline surrogates as fuel. Energy Conversion and Management. Vol. 183 Pp. 296-306. (2019) 